\title{
PENGEMBANGAN DAN PENGORGANISASIAN MASYARAKAT
}

\section{Resqy Rhaudatul Jannah}

Universitas Islam Negeri Alauddin Makassar

Email : khikyrj26@gmail.com

\section{PENDAHULUAN}

Pengorganisasian masyarakat adalah pengembangan yang mengutamakan pembangunan kesadaran kritis dan penggalian potensi pengetahuan lokal masyarakat. Pengorganisasian masyarakat mengutamakan pengembangan masyarakat berdasarkan dialog atau musyawarah yang demokratis. Pengorganisasian masyarakat juga memaklumi arti penting pembangunan sarana-sarana fisik yang dapat menunjang kemajuan masyarakat, namun titik tekan pembangunan itu ialah pengembangan kesadaran masyarakat sehingga mampu mengelola potensi sumberdaya mereka.

Secara umum, metode yang dipergunakan dalam pengorganisasian masyarakat adalah penumbuhan kesadaran kritis, partisipasi aktif, pendidikan berkelanjutan, pembentukan dan penguatan pengorganisasian masyarakat. Semua itu bertujuan untuk melakukan transformasi sistem sosial yang dipandang menghisap masyarakat dan menindas (represif). Tujuan pokok pengorganisasian masyarakat adalah membentuk suatu tatanan masyarakat yang beradab dan berperikemanusiaan (civil society) yang menjunjung tinggi nilai-nilai demokratis, adil, terbuka, berkesejahteraan ekonomis, politik dan budaya.

Pengembangan masyarakat adalah pengembangan yang lebih mengutamakan sifat fisik masyarakat. Pengembangan masyarakat mengutamakan pembangunan dan perbaikan atau pembuatan sarana-sarana sosial ekonomi masyarakat. Misalnya; pelatihan mengenai gizi, penyuluhan $\mathrm{KB}$, bantuan hibah, bantuan sekolah dan sebagainya. Dengan demikian, peningkatan pengetahuan, keterampilan dan penggalian potensi-potensi sosial ekonomi yang ada lebih diutamakan untuk mensukseskan target yang telah ditetapkan oleh pihak luar.

\section{Tujuan dari Pengembangan dan Pengorganisasian Masyarakat}

Mengembangkan peningkatan kapasitas dan daya tawar masyarakat (komunitas). Pemikiran ini bermuara pada prinsip demokrasi, yang menegaskan bahwa kedaulatan ada di tangan rakyat, atau suatu proses dari, oleh dan untuk rakyat. Secara mendasar pengorganisasian diarahkan untuk meningkatkankesadaran kritis masyarakat dan disisi lain mempersiapkan basis sosial bagi tatanan dan situasi yang baru dan lebih baik yang ingin diciptakan.

\section{Prinsip-prinsip Pengorganisasian Masyarakat}

Dari definisi dan pengertian pengorganisasian masyarakat, agar tujuannya dapat terwujud dan tidak keluar dari kerangka kerja pengorganisasian masyarakat maka ada prinsip-prinsip yang harus diperhatikan, yaitu: 
- Keberpihakan

Pengorganisasian masyarakat harus menitikberatkan pada lapisan bawah yang selama ini selalu dipinggirkan, sehingga yang menjadi basis pengorganisasian adalah masyarakat kelas bawah, tanpa mempunyai prioritas keberpihakan terhadap masyarakat kelas bawah seringkali pengorganisasian yang dilakukan terjebak pada kepentingan kelas menengah dan elit dalam masyarakat.

- Pendekatan holistik

Pengorganisasian masyarakat harus melihat permasalahan yang ada dalam masyarakat secara utuh dan tidak sepotong-sepotong, misalnya; hanya melihat aspek ekonomi saja, tetapi harusdilihat dari berbagai aspek sehingga pengorganisasian yang dilaksanakan untuk mengatasi berbagai aspek dalam masyarakat.

- Pemberdayaan

Muara dari pengorganisasian masyarakat adalah agar masyarakat berdaya dalam menghadapi pihak-pihak di luar komunitas (pelaku pembangunan lain; pemerintah, swasta atau lingkungan lain pasar, politik, dsb), yang pada akhirnya posisi tawar masyarakat meningkat dalam ber hubungan dengan pemerintah dan swasta.

- HAM

Kerja-kerja pengorganisasian masyarakat tidak boleh bertentangan dengan HAM.

- Kemandirian

Pelaksanaan pengorganisasian masyarakat harus ditumpukan pada potensi yang ada dalam masyarakat, sehingga penggalian keswadayaan masyarakat mutlak diperlukan. Dengan demikian apabila ada faktor luar yang akan terlibat lebih merupakan stimulan yang akan mempercepat proses perubahan yang dikehendaki. Apabila hal kemandirian tidak bisa diwujudkan, makaketergantungan terhadap faktor luar dalam proses pengorganisasian masyarakat menjadi signifikan. Kemandirian menjadi sangat penting karena perubahan dalam masyarakat hanya bisa terjadi dari masyarakat itu sendiri.

- Berkelanjutan

Pengorganisasian masyarakat harus dilaksanakan secara sistematis dan masif, apabila tujuannya adalah untuk meningkatkan posisi tawar masyarakat, oleh sebab itulah dalam melaksanakan pengorganisasian masyarakat harus mampu memunculkan kader-kader masyarakat dan pengorganisasi lokal, karena merekalah yang akan terus mengembangkan pengorganisasian yang sudah jalan sehingga kegiatan ini terjamin keberlanjutannya.

- Partisipatif

Salah satu budaya yang dilahirkan oleh Orde Baru adalah 'budaya bisu' dimana masyarakat hanya dijadikan alat untuk legitimasi dari kepentingan kelompok dan elit. Kondisi semacam ini tercermin dari kegiatan pengerahan masyarakat untuk mencapai kepentingan-kepentingan sesaat, oleh sebab itulah dalam pengorganisasian masyarakat harus diupayakan keterlibatan semua pihak terutama masyarakat kelas bawah. Partisipasi yang diharapkan adalah partisipasi aktif dari anggota sehingga akan melahirkan perasaan memiliki dari organisasi yang akan dibangun.

- Keterbukaan

Sejak awal dalam pengorganisasian masyarakat harus diupayakan keterbukaan dari semua pihak, sehingga bisa dihindari intrik dan provokasi yang akan merusak tatanan yang telah dibangun. Pengalaman yang ada justru persoalan 
keterbukaan inilah yang banyak menyebabkan perpecahan dan pembusukan dalam organisasi masyarakat yang telah dibangun.

- Tanpa kekerasan

Kekerasan yang dilakukan akan menimbulkan kekerasan yang lain dan pada akhirnya menjurus pada anarkhisme, sehingga diupayakan dalam berbagai hal dalam pengorganisasian masyarakat harus mampu menghindari bentuk-bentuk kekerasan baik fisik maupun psikologi dengan demikian proses yang dilakukan bisa menarik simpati dan dukungan dari berbagai kalangan dalam melakukan perubahan yang akan dilaksanakan.

- Praxis

Proses pengorganisasian masyarakat harus dilakukan dalam lingkaran AksiRefleksi-Aksi secara terus menerus, sehingga semakin lama kegiatan yang dilaksanakan akan mengalami peningkatan baik secara kuantitas dan terutama kualitas, karena proses yang dijalankan akan belajar dari pengalaman yang telah dilakukan dan berupaya untuk selalu memperbaikinya.

- Kesetaraan

Budaya yang sangat menghambat perubahan masyarakat adalah tinggalan budaya feodal. Oleh sebab itu pembongkaran budaya semacam ini bisa dimulai dengan kesetaraan semua pihak, sehingga tidak ada yang merasa lebih tinggi (superior) dan merasa lebih rendah (inferior), dengan demikian juga merupakan pendidikan bagi kalangan kelas bawah untuk bisa memandang secara sama kepada kelompok-kelompok lain yang ada dalam masyarakat, terutama dalam berhubungan dengan pemerintah dan swasta.

\section{Langkah-langkah Pengorganisasian Masyarakat}

Adapun tindak lanjut yang dimaksud meliputi tahapan langkah-langkah pengorganisasian masyarat yang terdiri dari:

1. Langkah integrasi, yaitu kegiatan yang dilakukan oleh organisator dengan meleburkan dirinya dalam masyarakat sehingga diterima masyarakat dan memahami kondisi masyarakat.

2. Riset sosial, yaitu dengan mempelajari lebih mendalam situasi sosio-kultural, historis dan masalah yang ada di masyarakat.

3. Program tentatif, yaitu menyusun serangkaian kegiatan yang dapat mendorong masyarakat sehingga masyarakat dapat berperan secara efektif dalam melakukan aktivitas penanganan masalah.

4. Aktivitas pemberdayaan, yaitu dengan membangun kesadaran melalui motivasi dan nilai-nilai moralitas.

5. Pertemuan dan Role Playing, yang melakukan pembahasan secara formal sehingga terdapat legitimasi dari masyarakat mengenai tindak lanjut pelaksanaan upaya yang akan dilakukan dalam penanganan masalah. Di samping itu, disiapkan pula langkah-langkah tindak lanjutnya agar jelas bagi masyarakat untuk terlibat.

6. Pelaksanaan Aksi, yaitu melakukan kegiatan pengorgniasasian masayarakat dalam penanganan masalah. Dalam hal ini perlu diidentifikasi jenis aksi, metode aksi, struktur aksi, tujuan dan target aksi.

7. Evaluasi, yaitu dengan melakukan kajian ulang mengenai proses maupun dari aktivitas pengorganisasian masyarakat. 


\section{Metode dan Media Pengorganisasian Masyarakat}

Pentingnya mengetahui metode dan media pengorganisasian masyarakat karena sarana yang akan digunakan akan membuat langkah-langkah yang sudah disusun dapat berjalan dengan efektif dan tepat sasaran. $\mathrm{Di}$ samping itu, dalam pengorganisasian masyarakat adalah penting dalam upaya memenangkan dukungan dan pemikiran masyarakat.

Beberapa bentuk metode dan media pengorganisasian masyarakat adalah sebagai berikut:

1. Diskusi, baik yang bersifat formal maupun yang bersifat informal (privat). Diskusi formal dilakukan secara terbuka dengan melibatkan seluas-luasnya anggota masyarakat dari segala macam lapisan. Sedangkan diskusi informal (privat) adalah diskusi yang melibatkan komunitas secara lebih spesifik

2. Pelatihan, yang ditujukan pada anggota masyarakat yang nantinya akan mampu menjadi aktor utama dalam pengorganisasian masyarakat.

3. Bentuk-bentuk aksi juga dapat menjadi sarana pengorganisasian masyarakat dimana suatu aksi yang memberikan impresi yang positif di mata masyarakat juga memiliki potensi untuk meningkatkan partisipasi dalam pengorganisasian tersebut.

4. Salah satu sarana lainnya adalah sarana yang memiliki karakter penyebaran yang lebih luas dan merata yaitu kampanye dan sosialisasi. Sarana ini dapat dilakukan dalam berbagai cara yaitu dalam bentuk selebaran, radio komunitas, buletin/buku, majalah/koran, video dan seni pertunjukan. 


\section{Daftar Pustaka}

muhammadiyah-bengkulu.org

pencerah.blogspot.com

id.shvoong.com

https://ppsw.or.id/index.php/2012/02/28/pengorganisasian-masyarakat/ 